\title{
Self-Supply as an Alternative Approach to Water Access in Rural Scattered Regions: Evidence from a Rural Microcatchment in Colombia'
}

\section{Autoabastecimiento como un enfoque alternativo para el acceso al agua en regiones rurales dispersas: evidencia en una microcuenca rural en Colombia ${ }^{2}$}

\author{
Isabel Domínguez ${ }^{3}$ \\ Wilmar Torres-López ${ }^{4}$ \\ Inés Restrepo-Tarquino \\ Charlotte Paterson ${ }^{6}$ \\ Jobn Gowing ${ }^{7}$
}

doi:10.11144/Javeriana.iyu20-1.ssaa

How to cite this article:

I. Domínguez, W. Torres-López, I. Restrepo-Tarquino, C. Paterson, and J. Gowing, "Self-supply as an alternative approach to water access in rural scattered regions: evidence from a rural microcatchment in Colombia," Ing. Univ., vol. 20, no. l, pp. 107-126, 2016. http://dx.doi.org/10.11144/Javeriana.iyu20-1.ssaa

\footnotetext{
'Submitted on: March 9 $9^{\text {th }}, 2015$. Accepted on: September 15 1 th 2015. This work was funded by the Administrative Department of Science and Technology from Colombia (Colciencias) through the doctoral training program "Francisco José de Caldas" [Call 497-2009], and from the International Foundation for Science (IFS) [Grant S/5155].

${ }^{2}$ Fecha de recepción: 9 de marzo de 2015. Fecha de aceptación 15 de septiembre de 2015. Este trabajo fue financiado por el Departamento Administrativo de Ciencia y Tecnología de Colombia (Colciencias), a través del programa de formación doctoral Francisco José de Caldas [Convocatoria 497-2009] y de la Fundación Internacional para la Ciencia (IFS) [Subvención S/5155]. ${ }^{3}$ Ingeniera sanitaria, Universidad del Valle, Cali, Colombia. MSc. In Water and Environmental Management, Loughborough University, UK. PhD in Water Resources, Newcastle University, UK. Profesora auxiliar de la Escuela de Ingeniería Civil de la Universidad Industrial de Santander, Bucaramanga, Colombia. E-mail: isabeldr@uis.edu.co

${ }^{4}$ Estadístico, Universidad del Valle, Cali, Colombia. Profesor, Universidad del Valle. E-mail: wilmar.alexander.torres@ correounivalle.edu.co

${ }^{5}$ Ingeniera sanitaria, Universidad del Valle, Cali, Colombia. MSc. en Ingeniería de Sistemas, Universidad del Valle. PhD in Knowledge Transfer, University of Leeds, UK. Profesora asociada, Instituto Cinara-Universidad del Valle. E-mail: ines. restrepo@correounivalle.edu.co

${ }^{6}$ Civil Engineer, Newcastle University, UK. MEng in Civil and Environmental Engineering, Newcastle University. PhD in Environmental Engineering, Newcastle University. Senior Lecturer at the School of Civil Engineering \& Geosciences, Newcastle University. E-mail: charlotte.paterson@ncl.ac.uk

${ }^{7}$ Agricultural Engineer. BSc in Engineering Science, University of Durham, UK. MSc in Agricultural Engineering, Cranfield University, UK. Reader in Agricultural Water Management at the School of Agriculture, Food \& Rural Development, Newcastle University, UK. E-mail: john.gowing@ncl.ac.uk
} 


\section{Abstract}

Globally, access to improved water sources is lower in rural areas compared to urban areas. Furthermore, in rural areas many people use water from individual systems they have developed with their investments, often without external support. This phenomenon has been called Self-supply. Self-supply ranges from simple to complex systems and different water sources. Water quality varies, from achieving the microbial World Health Organization (WHO) standard (0 Colony Forming Units per 100 millilitres $\mathrm{CFU} / 100 \mathrm{ml}$ ) to systems that provide water posing high risks to human health. While most studies in Self-supply have been developed in Africa, little is known in Latin America and the Caribbean (LAC). This research explores Self-supply in a rural microcatchment in Colombia (LAC). This research collected and analysed data from household and drinking water surveys. Results showed that $40 \%$ of households used Self-supply systems taking water from springs and brooks. Thermotolerant Coliforms were below $50 \mathrm{CFU} / 100 \mathrm{ml}$, during both dry and rainy season, and between 5 to $7 \%$ of samples achieved the microbial WHO standard. These results suggest that Self-supply has potential to offer safe drinking water, provided improvements on source protection and institutional support. Therefore, Self-supply could contribute to address "unfinished business", including ensuring access for the hardest-to-reach people, as stated in the United Nations post-2015 development agenda.

\section{Keywords}

self-supply; water quality; Thermotolerant coliforms; rural areas; Colombia

\section{Resumen}

Globalmente, el acceso a fuentes de agua mejoradas es menor en el campo que en las ciudades. Además, muchas personas del campo usan fuentes de agua individuales desarrolladas sin apoyo externo o autoabastecimiento. Este último incluye sistemas desde simples a complejos, que usan diferentes fuentes con una calidad que cumple los estándares microbiológicos de la Organización Mundial de la Salud (0 unidades formadoras de colonias por 100 mililitros [CFU/100 ml]), hasta sistemas que suministran agua con altos riesgos para la salud. Mientras la mayoría de los estudios se reportan en África, poco se conoce en Latinoamérica y el Caribe (LAC). Esta investigación recogió y analizó datos de encuestas de hogares y calidad de agua en una microcuenca rural en Colombia (LAC). El $40 \%$ de las viviendas dependía del autoabastecimiento usando quebradas. Las coliformes termotolerantes fueron menores de $50 \mathrm{UFC} / 100 \mathrm{ml}$ en época seca y época lluviosa, y entre el $5 \%$ y el $7 \%$ de las muestras alcanzaron el estándar de la Organización Mundial de la Salud. Estos resultados sugieren que el autoabastecimiento tiene potencial para suministrar agua segura, si se mejoran la protección de las fuentes y el apoyo institucional, y podría contribuir a abordar "asuntos no terminados", incluido el acceso al agua de "gente difícil de atender", propuesto en la agenda de desarrollo pos-2015 de las Naciones Unidas.

\section{Palabras clave}

autoabastecimiento; calidad de agua; coliformes termotolerantes; áreas rurales; Colombia 


\section{Introduction}

The commitment to the Millennium Development Goals (MDGs) made by the countries of the world to increase water access have represented significant improvements to many people around the globe. WHO and Unicef [1] emphasize that by 2012, $89 \%$ of the world population had access to an improved water source, although, progress had been unequal between regions, urban and rural areas, and disadvantaged populations, with still 784 million people without access to improved sources, from which $90 \%$ live in rural areas.

Often, rural areas that seem to lack access to improved sources are users of individual systems. Such individual systems have recently been considered as a potential alternative for access to water, under an approach named Self-supply [2]-[7]. In Self-supply, families or neighbours invest their own resources to develop their water systems, independent of public investment on infrastructure [2], [7], [8]. Systems are based on low-costs technologies [8], that range from simple to advanced options, depending on the economic capacity of the users [6], and even the poorest people can make investments to build their supplies [7]. Reported sources are typically groundwater [2], [3], [6], [8]-12], protected or unprotected, according to WHO [13]. Individuals invest in these systems motivated by personal convenience, desire for self-improvement, and possibilities for productive water use [3]. Therefore, self-supply is generally associated to strong ownership [2], [6]-[8], and considered likely to be more sustainable than communal approaches in which the sense of ownership tends to be problematic [3], [7].

Self-supply exists in urban contexts [8]-[10], [12], [14], but it is more frequent in low density and scattered rural communities [6], in places where there is insufficient coverage or poor performance of communal systems [6], [7]. Due to these characteristics, Self-supply is increasingly considered a service delivery model complementary to community level provision [2], due to its potential to fill gaps left by other forms of water provision [8], particularly in areas where 
water is distant, unreliable, and costly [3]. It has been argued, these systems can be incrementa lly improved and are easily replicable [7].

Most research on Self-supply has been carried out in Africa: Niger, Ghana, Liberia, Sierra Leone, Mali, Senegal [7]; Ethiopia [2], Madagascar [8], [9], Kenya [10], [12], Uganda [3], and Zambia [6]. Studies assess potential for Self-supply or report results from piloting models [7]. Issues addressed include: technologies $[2],[6],[8],[11]$; water quality $[2],[6],[8]-[11]$; socio-economic profile of users; water use and handling practices [12]; enabling environment required for scaling up [2], [10], and performance and motivations for investment [2]. Pilots in African countries reported the reduction in health risks, high levels of cost covering by householders, and the transferability of improvements [7].

The potential long-term environmental impacts, such as depletion of water sources in high-density areas depending on groundwater sources, which are ineffectively managed, have been concerns on Self-supply [2], [10]. The idea of the poorest people making the major investments to ensure their access to water through Self-supply systems has also been criticized [10]. Besides these concerns, water quality has been a major issue of debate. The evidence on water quality in these systems is mixed. Generally, there is a proportion of Self-supply systems providing water quality with low microbiological risk (i.e. below 0 CFU/100 $\mathrm{ml}$ ), whereas other systems present high levels of microbiological contamination (i.e. above $100 \mathrm{CFU} / 100 \mathrm{ml}$ [ [6], [10], [11]. This, however, contrasts with the widespread perception of poor quality among water sector professionals [2], [6], [7]. This perception is mainly due to a lack of sufficient information available about Self-supply systems compared to communal sources [2], [10].

In LAC, coverage of access to improved sources reached $94 \%$, with a $9 \%$ increase between 1990 and 2012 [1]. In this region, there is no published information on individual supply systems, from the perspective of Self-supply. In Colombia, while coverage in access to improved water sources in urban areas was reported at $97 \%$ in both 1990 and 2012, in rural areas coverage increased from $69 \%$ to $74 \%$ in the same period [1], ranging between $58 \%$ and $88 \%$, depending on the region [15]. Despite this positive trend, the National Planning Department recognizes that information on the conditions of access to water in scattered communities is scarce, particularly in relation to water quality. It also acknowledges that scattered and nucleated rural areas need differentiated approaches to water provision [15], which could make Self-supply a recognized alternative to progress towards improved access to water. 
This study provides quantitative evidence on the presence of Self-supply systems in scattered households in a Colombian Microcatchment. Information on the proportion, distribution, technologies, and water quality provided by these systems is included, together with a reflection on the potential to consider "supported" Self-supply [2], [5] as a complementary strategy to progress towards reducing the urban - rural gap on access to water in rural regions of Colombia.

\section{Methods}

The research followed a single case design [16]. The place selected for the study was Calabazas, a small microcatchment in Colombia. Calabazas was selected because a Non-Governmental Organization (NGO) developed a project with interventions on natural resources conservation and farmers' wellbeing in this area. Data was gathered through a household survey and water quality monitoring. Data was collected taking into account hydrological boundaries, based on the consideration of the catchment as the effective unit to address water quality issues [17].

\subsection{The Study Area}

Calabazas Microcatchment is located in the Andean region in Colombia, at $4^{\circ}$ 05' North Latitude and $76^{\circ} 37^{\prime}$ West Longitude. The climate presents a bimodal behaviour with two rainy (April-June and October-November) and two dry seasons (January-March and July-August) [18].

For 2013, the microcatchment population was estimated to have 850 inhabitants, $40 \%$ women and $60 \%$ men. The average household size was three and $13 \%$ of households had at least one child under 5 years old. The economy depended on the agricultural and livestock sectors. Farm production was mostly coffee associated with plantain and banana, and animal husbandry including poultry, and small units of pigs and cows.

Calabazas has a range of altitudes between 1000 and $1900 \mathrm{~m}$. Coffee farms were typically less than $3 \mathrm{ha}$, and located from 1300 to $1800 \mathrm{~m}$, occupying about $63 \%$ of the catchment area. Between $1300 \mathrm{~m}$ and $1000 \mathrm{~m}$, farms were dedicated to livestock (32\% of the area). There was productive forest and protective forest in $2 \%$ and $3 \%$ of the land, respectively. The microcatchment was an example of land use change processes. For instance, according to the environmental authority, $21 \%$ of the area should be under protective forest, contrasting with the existent $3 \%$ coverage of this land use [19].

Regarding water quality in the main stream, a basic characterization carried out within this research (Table 1) shows that despite a small decline from 
upstream to downstream in conductivity, other parameters remained at levels that characterize unpolluted water bodies. The variation of parameters such as Temperature, Dissolved Oxygen (DO), and $\mathrm{pH}$ had a closer association with geology and topography than with land use. This coincides with findings from a study in another small Andean catchment from Valle del Cauca Department (Colombia) [20]. Biochemical Oxygen Demand (BOD) and Total Suspended Solids (TSS) are not included in Table 1 because their values were always below the detection limits of the methods used (BOD $<3.0 \mathrm{mg} / \mathrm{L}$, and TSS $<5 \mathrm{mg} / \mathrm{L}$ ). Thus, despite land use change and human influences, Calabazas could be considered an unpolluted source.

Table 1. Flow and water quality in Calazas

\begin{tabular}{|c|c|c|c|c|c|c|}
\hline \multirow[b]{2}{*}{ Parameter* } & \multirow[b]{2}{*}{ Season } & \multicolumn{2}{|c|}{ Headwaters } & \multicolumn{2}{|c|}{ Catchment outlet } & \multirow{2}{*}{$\begin{array}{c}\text { Values for } \\
\text { unpolluted } \\
\text { natural surface } \\
\text { waters [21] }\end{array}$} \\
\hline & & Mean & $\begin{array}{l}\text { Standard } \\
\text { deviation }\end{array}$ & Mean & $\begin{array}{l}\text { Standard } \\
\text { deviation }\end{array}$ & \\
\hline \multirow{2}{*}{ Flow $(1 / s)$} & Rainy & 3.8 & 0.7 & 429.2 & 129.6 & \multirow{2}{*}{ Not applicable } \\
\hline & Dry & 4.7 & 0.6 & 232.5 & 39.7 & \\
\hline \multirow{2}{*}{$\mathrm{pH}$ (units) } & Rainy & 7.9 & 0.4 & 8.0 & 0.3 & \multirow{2}{*}{$6.0-8.5$} \\
\hline & Dry & 7.3 & 0.5 & 7.9 & 0.1 & \\
\hline \multirow{2}{*}{$\begin{array}{l}\text { Temperature } \\
\left({ }^{\circ} \mathrm{C}\right)\end{array}$} & Rainy & 17.6 & 0.3 & 21.5 & 0.5 & \multirow{2}{*}{$0.0-30.0$} \\
\hline & Dry & 18.3 & 0.1 & 23.7 & 1.1 & \\
\hline \multirow{2}{*}{$\begin{array}{l}\text { Conductivity } \\
(\mu \mathrm{S} / \mathrm{cm})\end{array}$} & Rainy & 108 & 29 & 136 & 38 & \multirow{2}{*}{$<1000$} \\
\hline & Dry & 125 & 14 & 168 & 5 & \\
\hline \multirow{2}{*}{$\mathrm{DO}(\mathrm{mg} / \mathrm{L})$} & Rainy & 6.96 & 0.53 & 7.53 & 0.46 & \multirow{2}{*}{$5-10$} \\
\hline & Dry & 5.99 & 0.84 & 6.52 & 1.41 & \\
\hline
\end{tabular}

"n $=4$ for all parameters at each station.

Source: authors' own elaboration

\subsection{Sample Frame}

Local leaders were identified using a snowball sampling approach [22], with help from the Social Worker of the NGO that had undertaken different programs in the area, the Departmental Committee of Coffee Growers (DCC). These leaders were contacted in advance to discuss different aspects of the research (i.e. phases, data collection strategies, and the information to be delivered to them from the investigation). 
Local leaders helped to establish the study area population by triangulation of three information sources: i) Database of coffee farms provided by DCC [23], ii) distribution network maps for the communal water supply systems, and iii) mapping exercises to complete missing information or to clear records of empty houses, or plots without houses. Leaders identified the water sources for each household through these mapping exercises. A map was prepared including: the microcatchment drainage network, farm location from a Geographic Information System database provided by DCC, and livestock farms. Livestock farms were initially placed by hand on the map by community members, and later they were visited and geo-referenced using a Global Positioning System (GPS) (Garmin GPS map 60CSX). The microcatchment map was divided into smaller drainage areas (33 areas) and for each resulting drainage area, the number of households being supplied by each water system was established (communal and Self-supply) (Figure 1).

Figure 1. Location of households with Self-supply systems in Calabazas

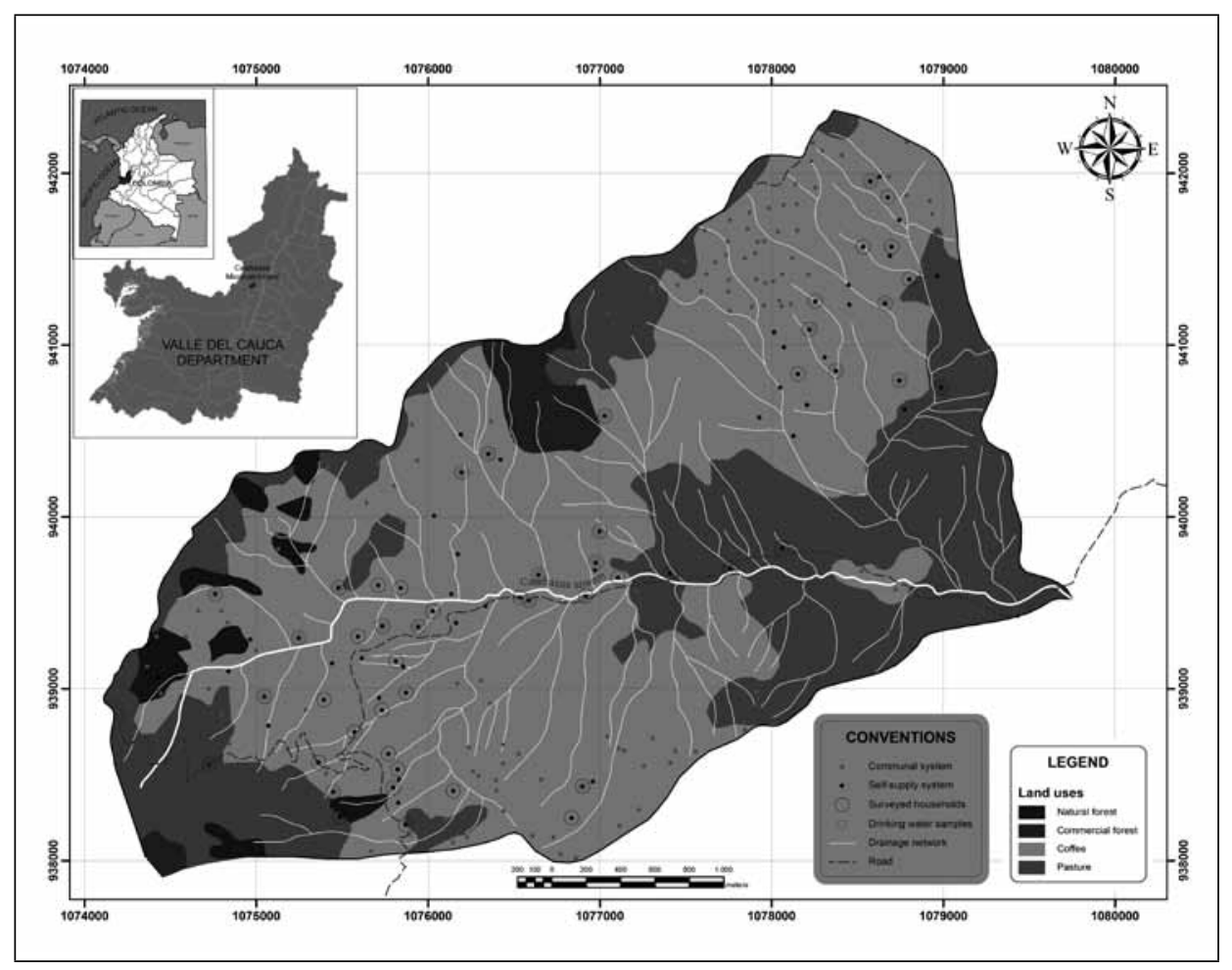

Source: authors' own elaboration 


\subsection{Housebold Survey}

Due to the scattering of the dwellings and the difficult access, as a rule of thumb [22], the household survey was applied to 100 households ( $40 \%$ of the population). These households were randomly selected according to drainage area, taking proportionally the number of houses belonging to each water supply alternative (communal and Self-supply), where possible. The survey contained 15 sections: demography, education, employment, livelihoods, access to water, sanitation, solid waste management, animal husbandry, access to health care, perceptions and cases of diarrhoea, among others. Only data on people perceptions on water quality and water management practices at the household level is reported here. A detailed account of the survey methodology and results can be found in [24]. Local leaders were trained as enumerators. The training included overviews of the research and the household survey, relevance of the questions, wording, understanding of different terms, aspects of informed consent, and bias. A practical example was developed and enumerators received questionnaires to practice and a glossary explaining terms.

The questionnaire was reviewed, checked and printed, and a list of people to interview was prepared for each of the enumerators. An additional list of houses available for replacement, in case of potential problems with houses in the main list, was provided explaining the criteria for replacement (i.e. drainage area and water supply system). A second training session was carried out to ensure procedures were developed according to the study needs.

Data collection took place from February $8^{\text {th }}, 2013$, to April 18 th, 2013. The questionnaires were administered through face-to-face interviews. Household members aged 18 or older were targeted as respondents.

\subsection{Drinking Water Survey}

The drinking water survey involved 50 households (20\% of the population), that were randomly selected according to drainage area, and water supply alternative (communal and Self-supply). The number of households where water samples were taken (50) was selected considering: travel time between households, restrictions of time between sample collection and laboratory analysis, and number of samples that could be analysed with the available equipment, including duplicates. From the 50 households, 24 were users of communal systems. Therefore, only results from the 26 users of Self-supply systems are presented here.

Pilots were conducted in the south (March 12th, 2013) and north side (March 14th, 2013) of the microcatchment to organize logistics. Three people were 
trained in each side to collect samples simultaneously at selected points across the whole microcatchment to adhere to time restrictions from the methodologytime between collection to processing the samples of around 4 hours [25].

Four monitoring campaigns were carried out in the rainy season (March 18th, 2013-May 2 $2^{\text {nd }}, 2013$ ) and four in the dry season (July 9th, 2013-August $\left.14^{\text {th }}, 2013\right)$. Each campaign comprised one day taking samples in the south side of the microcatchment and one day in the north side. An average of eight samples in each of the 26 houses were taken, four samples in rainy season and four samples during the dry season. A total of 201 samples were analysed (98 in rainy season and 103 in dry season), since some samples could not be collected because of absence of water or people at some homes during the monitoring day ( 7 cases).

Water analyses were carried out using DelAgua Portable water testing kits following the manufacturer's procedures [25]. Samples were analysed for the parameters suggested by WHO [13],[26]: Thermotolerant Coliforms (TTC), $\mathrm{pH}$, turbidity, and residual chlorine. Samples for microbial analysis were stored in sterile polypropylene containers of $125 \mathrm{ml}$, reserved in polystyrene coolers with ice, and analysed within 4 hours from collection, with the membrane filtration method. Each monitoring day duplicates were analysed for seven randomly selected water samples following recommendations from WHO [26].

\subsection{Data Analysis}

Data from the questionnaires in the household survey were transferred into an Excel 2010 database. Tables and charts were prepared to display the behaviour of the values of variables studied. Results from the drinking water survey were recorded in designed forms and transferred to an Excel 2010 database. Descriptive statistics were computed to characterize Self-supply in relation to TTC and season. Data on $\mathrm{pH}$ and Turbidity were generally within the range of safe water and showed low variability. The samples never had residual chlorine. Therefore, only data on microbial quality (TTC) were statistically analysed and are reported here. Dataset distribution was established according to season (Shapiro-Wilk) and between seasons (Mann-Whitney). The percentage of samples in a given TTC level was established. Descriptive statistics were computed in Excel 2010 and statistical tests were performed with the freely available software $\mathrm{R}$ version 2.15 .2 (http://www.r-project.org/). 


\section{Results and Discussion}

\subsection{Access to Water}

Based on the mapping exercises, it was established that $40 \%$ of homes had individual water systems, Self-supply. All the households with Self-supply systems relied on this single source for all their water needs. Houses took water from unprotected springs, and conducted using hoses to enjoy a household connection. These systems are common across mountain regions in the Andes, where sources are characterized by temporally and spatially heterogeneous water availability [20]. This Self-supply based on a single surface water source is different from that reported in studies from African contexts, where Self-supply is mainly dependent on multiple sources, commonly groundwater [2], [3], [6]-[12]. These Self-supply systems in Calabazas would be likely categorized as "unimproved sources" by WHO [13], [26].

\subsection{Microbial Water Quality}

In the Self-supply systems from Calabazas, median TTC counts were slightly higher for dry season ( $46 \mathrm{CFU} / 100 \mathrm{ml}$ ) compared to rainy season ( $44 \mathrm{CFU} / 100 \mathrm{ml}$ ). However, TTC levels were below $50 \mathrm{CFU} / 100 \mathrm{ml}$ in both seasons. According to WHO [26], this level of microbial pollution when analysed together with results from sanitary surveys - that were not part of this research — could fall on a category of high risk that will require actions of high priority. However, some authors consider the WHO standard too restrictive and unrealistic for rural systems supplying untreated water [27], [28]. Furthermore, as part of the post-2015 MDG agenda, more flexible standards (i.e. less than $10 \mathrm{CFU} / 100 \mathrm{ml}$ ) are being considered more suitable as an intermediate level of access to safe water in rural areas [29]. In Uganda, a mediumterm standard of $50 \mathrm{CFU} / 100 \mathrm{ml}$ for untreated water is used [28].

Despite median TTC levels below 50 CFU/100 mL, microbial water quality was variable. TTC counts in rainy season ranged between 0 and 1800 CFU/100 $\mathrm{ml}$. In dry season the range was $0-2360 \mathrm{CFU} / 100 \mathrm{ml}$. In addition, the standard deviations were $279 \mathrm{CFU} / 100 \mathrm{ml}$ and $271 \mathrm{CFU} / 100 \mathrm{ml}$ in rainy season and dry season, respectively. Greater quantity of atypical data occurred during the rainy season, but the magnitude of the atypical data was greater in dry season (Figure 2). Thus, the systems had peak TTC levels for both dry and rainy season, estimated around $2000 \mathrm{CFU} / 100 \mathrm{ml}$, which demand the introduction of measures to reduce the risk for human health when sudden events of pollution occur. These sudden events or pulses of microbial pollution in dry season were found by Levy et al. [30] in Ecuador associated to sporadic rains during said season. 
Figure 2. Box and whisker plot of TTC in Self-supply systems according to season

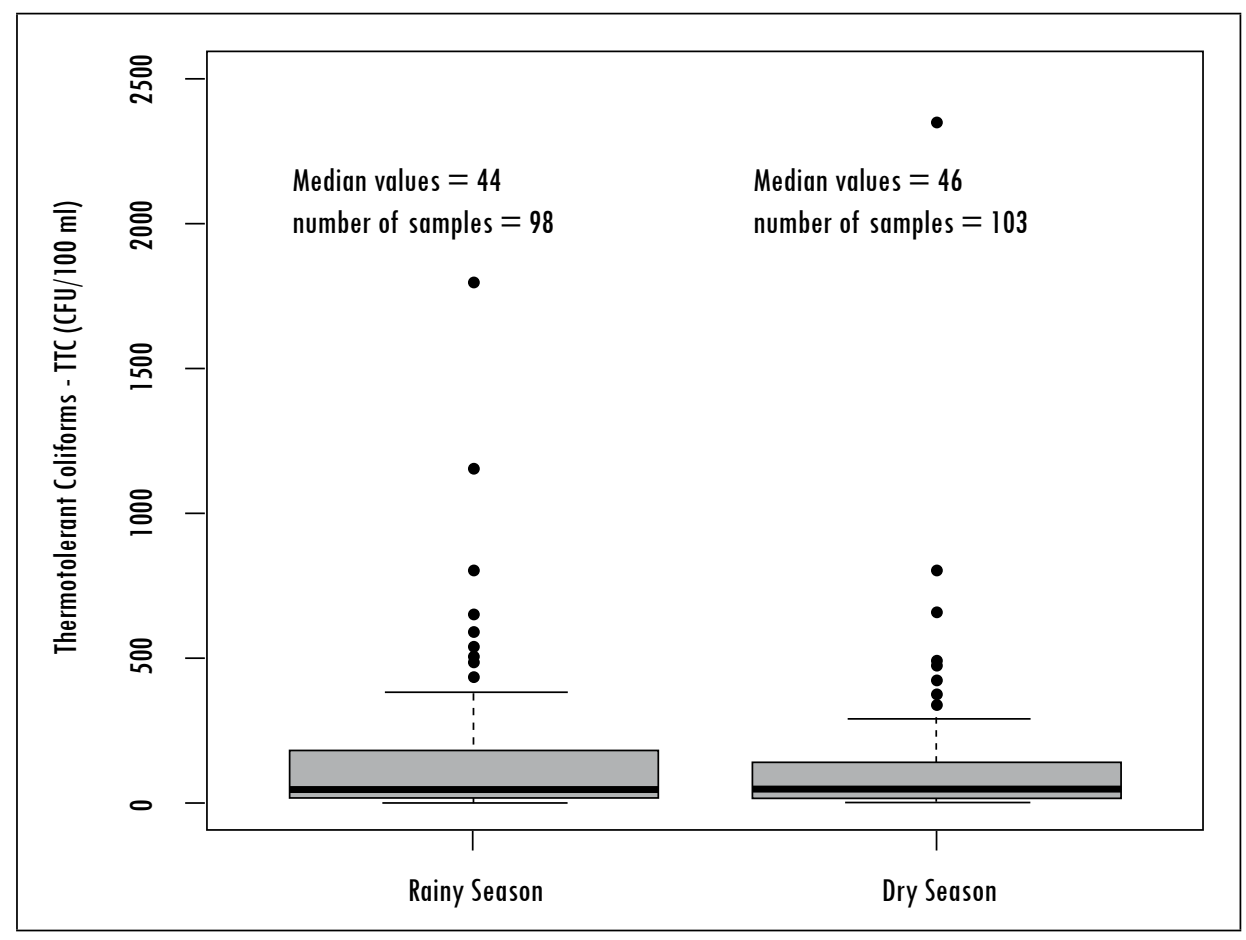

Source: authors' own elaboration

There were no statistically significant differences between rainy season, compared to the dry season (Mann-Whitney, $\mathrm{p}=0.6188$ ). The lack of statistically significant differences in microbial water quality between seasons contrasts with studies in rural areas of Tanzania [31] and Ecuador [30], where higher microbial levels were found in domestic sources in rainy season, associated with faecal contamination in the surrounding environment flushed to water sources due to increased runoff. In Calabazas, this lack of statistically significant differences between seasons may be explained on the fact that $95 \%$ of the population had access to improved sanitation [1], from which $45 \%$ included secondary treatment systems. The secondary treatment systems included: grease trap, septic tank, and up-flow anaerobic filter. These systems were implemented through programs led by governmental and non-governmental organizations. This highlights the importance of sanitation as a preventive approach to address water quality at the catchment level [32], [33]. 
Figure 3 shows TTC levels according to the season. It is worth noting that $5 \%$ of samples were in the category of less than $1 \mathrm{CFU} / 100 \mathrm{ml}$ for dry season and $7 \%$ for rainy season, meeting the microbial WHO standard. Two among the 26 participating households $(8 \%)$ met the standard for both rainy and dry season. The WHO standard has been achieved by $27 \%$ of Self-supply systems in Madagascar [8], from 5 to $47 \%$ systems, depending on source types in Ethiopia [2], and by around 35\% in Zambia [6]. In all the international studies reviewed, self-supply systems depend on groundwater sources, and no studies were found from the perspective of Self-supply where systems relied on surface water sources such as Calabazas. However, the comparison between the Calabazas case and the international cases shows that, regardless of the water source and the specific contexts, individual families are able to build and operate systems that provide water with less than $1 \mathrm{CFU} / 100 \mathrm{ml}$, and the potential to adopt incremental approaches with external support to help systems failing to meet the standard to improve the delivery of safe water [2], [3]. These results support calls to consider Self-supply as a complementary strategy that allow countries to progress towards achieving universal access to safe water [2], [4], [5].

Figure 3. Level of Thermotolerant coliforms according to season

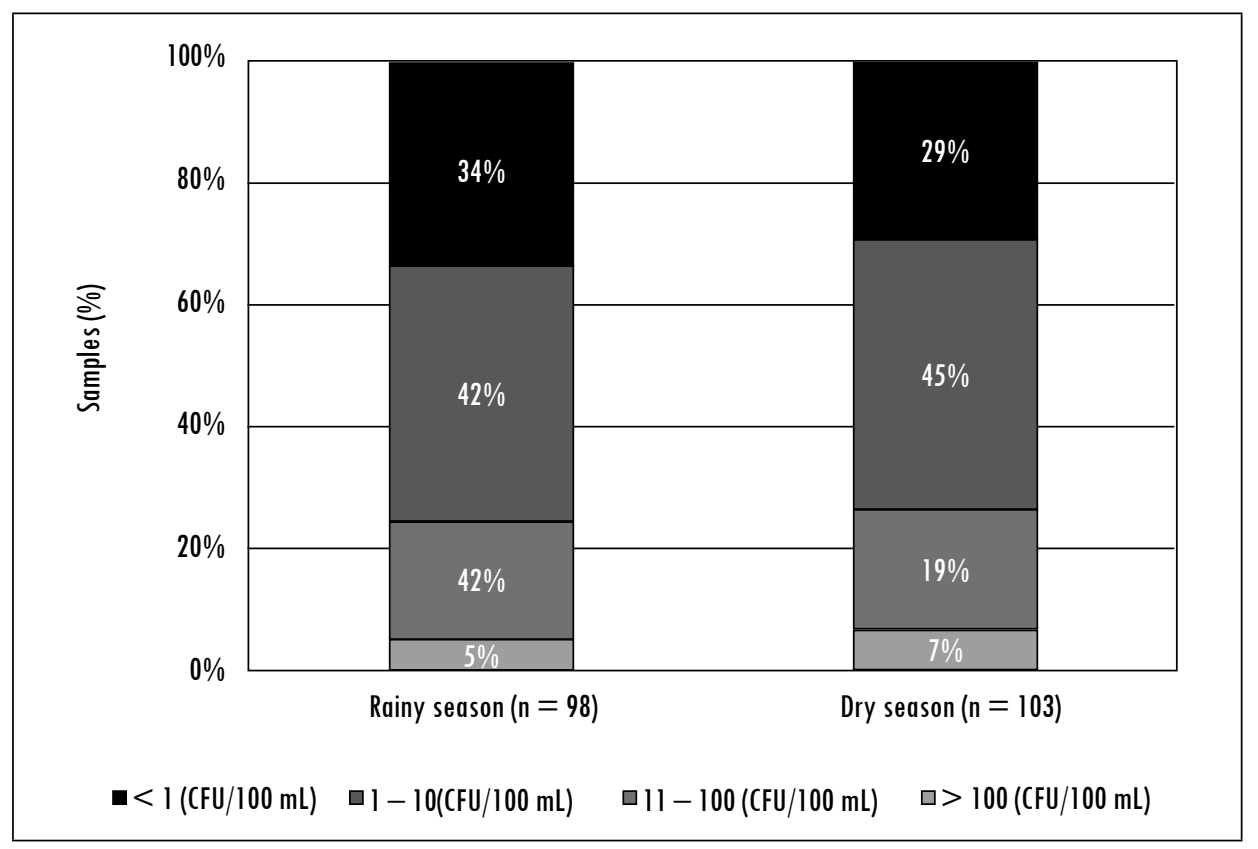

Source: authors' own elaboration 


\subsection{People Perceptions}

In most homes people had positive perceptions of their drinking water quality. In rainy season and dry season, $81 \%$ of households believed water quality was good or very good (Figure 4). These high levels of positive perceptions may be related to the direct involvement of families in the selection, operation, and maintenance of their systems. This is consistent with the reported strong sense of ownership of users towards the systems they have developed through their own efforts [2], [6]-[8]. On the other hand, this also shows the challenge of making people aware of the risks associated to their sources of supply, especially when there are no data available from water quality surveillance. In Colombia, water quality surveillance from sanitary authorities covers only $57 \%$ of the rural population, using collective systems [34]. In Madagascar, results from focus groups discussions revealed that some owners believed their water was potable, even though these water was untreated [10]. This highlights the need to support Self-supply users with education, technical advice, and water quality monitoring and surveillance to realise and mitigate the risks that are present in these systems (i.e. pollution pulses).

Figure 4. People perceptions on drinking water quality according to season

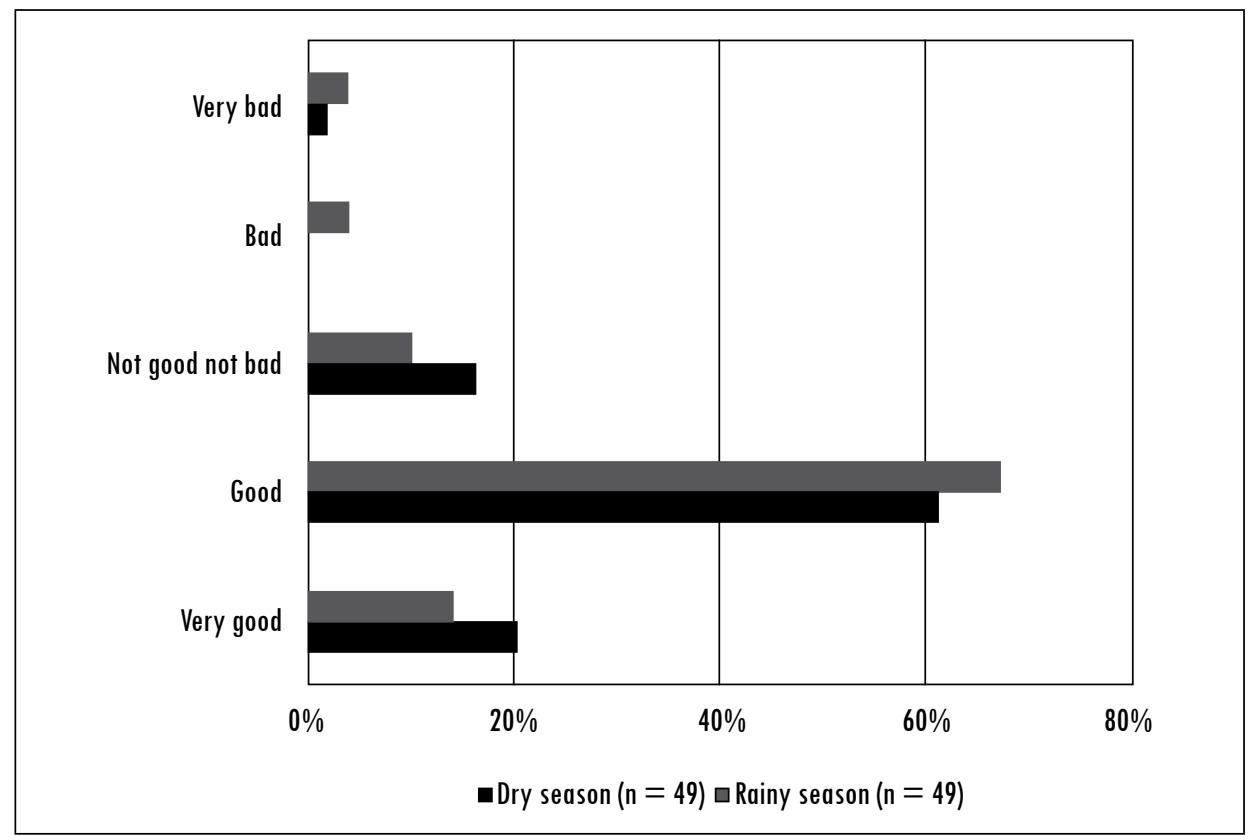

Source: authors' own elaboration 
Based on people perceptions on the good status of the intake areas (Table 2), mostly associated to be free of pollution and well forested, it could be inferred that Self-supply users made efforts on the protection of surrounding areas and preservation of their native forest. Protection of sources is considered one of the most effective strategies for providing safe water, since it can result in significant reduction of capital costs and Operation and Maintenance $(O \& M)$ [35]. In the cases in which the perception of the intake status was negative $(6 / 48)$, people understood it was due to the influence of wastewater discharges, animals or crops upstream, or insufficient forests. In addition, users tried to take water from sites free of pollution sources, and with coverage of native forest, which could contribute, together with sanitation, to reduce the impact of the rainy season over microbial water quality which is normally reported in the literature [28], [30].

Table 2. Perception of the state of the intake area

\begin{tabular}{|l|c|}
\hline \multicolumn{1}{|c|}{ Perceptions } & Counts \\
\hline Without pollution & 19 \\
\hline Well forested & 11 \\
\hline Clean & 7 \\
\hline Well look after & 5 \\
\hline Influenced by animals and crops upstream & 2 \\
\hline Influence by wastewater discharges upstream & 2 \\
\hline Insufficiently forested & 2 \\
\hline Total & 48 \\
\hline
\end{tabular}

Source: authors' own elaboration

\subsection{Housebold Water Storage and Treatment}

Water storage at the household level was reported by $41 \%$ of users of Self-supply systems. This may be due to low reliability of the sources, tendency to seasonal variations or dry-up, and the artisanal infrastructure prone to frequent damage. However this proportion is not too high, which could suggest that in most cases $(59 \%)$, quantity and continuity were adequate. Avoiding storage may also contribute to reduce the chances of intra-household water contamination and to improve hygiene [36]-[38].

In relation to Household Water Treatment (HWT), 33\% users developed this practice. Identical results were found in a study analysing HWT based on national survey information across several countries [39]. Low levels of HWT may be due to the high positive perception about the water quality [38]. In Calabazas, 
the treatment was boiling. In Colombia, coverage of electricity supply in the rural areas is estimated at $92.6 \%$ [40]. During fieldwork, it was observed that families combined electricity and wood for cooking. Therefore, the resources required for boiling water seem to be available. Boiling is considered one of the best ways to disinfect water because it is more effective against almost all kinds of infectious agents when compared with chlorine and filtration, which have limitations to eliminate protozoa and virus, respectively. However, boiling may be more expensive and environmentally harmful [39]. HWT strategies such as boiling can be promoted among users of Self-supply systems to minimize the hazards associated with the pulses of contamination that can occur immediately after sudden rains [28], [30], during transport in pipelines, [41] or in cases where water is stored at homes [39], [42].

\subsection{Reflections on the Potential for Self-supply in Colombia}

In Colombia, it is estimated that 11.2 million Colombians (23.1\%) live in rural areas, $77 \%$ in scattered regions, where investments in water supply are considered challenging. The challenges include: i) the restrained ability of the smallest municipalities to deal with technical, financial, and political aspects; ii) limitations for water quality surveillance due to a lack of trained staff and laboratories at the municipal level, and iii) lack of inventories and updated information on coverage and performance of implemented solutions [15].

Since 2006, the government policy looked to regionalize the provision of services, focusing on the urban population, thus, compromising progress in rural areas. The current Colombian policy for provision of drinking water and sanitation in rural areas aims to promote access to these services recognizing the need for differentiated approaches, where individual solutions are considered suitable alternatives to ensure access to drinking water in scattered regions [15]. The current policy is aligned with the aspirations of the proposed post2015 development agenda; its targets include: achieve universal access to basic drinking water; and halve the proportion of the population without access at home to safely managed drinking water services [1].

In this scenario, Self-supply could be considered a potential alternative to progress towards safely managed drinking water services, contributing to progress in both the national policy and the post-2015 agenda. The reported studies around the world [2]-[4], [7], [8], [11], [43] and Calabazas show Self-supply has potential in scattered rural areas, where it is expensive and technically difficult to lay communal piped systems, and for poor people with difficulties 
to pay water fees [5]. However, Self-supply feasibility depends on being recognized and supported by government agencies, as there are challenges about safety and reliability of water provision, and over-exploitation of limited water resources [2], [5].

Within this context, some recommendations to government institutions based on the Calabazas' case include developing policies about households' improvements in rural areas that consider Self-supply as a recognized alternative, and designing guidelines for the provision of water based on springs, streams, and rainwater harvesting. Policies and guidelines should include key issues such as the protection of springs, which generally led to improvements in water quality [35], and Water Safety Plans approaches that help to identify critical points and the required strategies to reduce risks [44]. HWT strategies such as boiling could be promoted to complement source protection, helping to reduce risks arising from contamination at the entire chain from the catchment to the user [45]. One step further will be for these systems to consider the multidimensional water needs of rural people, as suggested by the multiple uses approach [46], [47].

Although Calabazas seems to be a resilient catchment where land use change and human activities did not substantially affect water quality, a limiting factor for Self-supply in other catchments could be the deterioration of water resources due to both, water pollution and the reduction of flows. Pollution in rural catchments comes from domestic wastewater and agriculture-livestock activities, and the reduction in flows comes from deforestation, uncontrolled water abstraction, and climate change [48]. The role of environmental authorities and municipal planning offices is crucial to protect water resources so Self-supply could be a suitable alternative for rural areas.

\section{Conclusions}

Self-supply was explored in a microcatchment in the Andean region of Colombia, considering aspects such as access and water quality along with issues of people perceptions and water management at the household level.

The results from this case contribute to fill a gap on reliable, fine-scaled, geo-referenced data about drinking water infrastructure and water quality from individual systems [2], [10], [15]. The proportion of Self-supply systems providing water with less than $1 \mathrm{CFU} / 100 \mathrm{ml}$, endorse the consideration of alternative approaches for water provision in rural areas such as Self-supply [2], [4], [5]. The Self-supply approach being promoted takes advantage of the 
families' motivation to invest on their water systems, but demands recognition and support from government agencies [2].

In Colombia, individual systems start being recognized as a potential alternative to supply safe water in rural regions. Particularly in the Andean region, there are scattered areas with difficult topography, abundant and relative good water quality, which would benefit from the development and transfer of packages for the design, construction, and O\&M of water supply systems for individual households, encompassing multiple uses of water.

Features such as poor infrastructure on water, health, education, and roads; small farms, low population density, and livelihoods based on subsistence farming, make Calabazas a typical rural catchment from the Colombian Andes. However, the presence of institutions like DCC, and a sanitation coverage of $95 \%$ are factors which could make a difference on water resources status. Therefore, developing case studies on Self-supply in catchments with different characteristics could contribute to identify the determinant factors conditioning the potential for Self-supply in other rural areas.

Future research demands testing, demonstrating, and scaling-up technological solutions adjusted to scattered rural Andean regions, incorporating a multiple-barrier approach to incrementally progress access to safe water. In addition, models to support Self-supply users should also be developed. These models should help users on identifying and implementing low cost technologies, behavioural changes, such as household water treatment and storage, hygiene education, and water quality monitoring and surveillance.

\section{References}

[1] WHO and Unicef, Progress on drinking water and sanitation: 2014 update. Geneva: WHO (World Health Organization), 2014.

[2] J. Butterworth, S. Sutton, and L. Mekonta, "Self-supply as a complementary water services delivery model in Ethiopia," Water Alternatives, vol. 6, pp. 405-423, 2013.

[3] J. Kiwanuka, "Achievements and lessons learned from the Uganda self-supply pilot project 2006-2008," in 2009 34th WEDC International Conference-Water, Sanitation and Hygiene: Sustainable Development and Multisectoral Approaches, Addis Ababa, Ethiopia, 2009.

[4] K. Kumamaru, I. Smout, and F. Odhiambo, "Self-supply: Bridging the gap between household demand and community water supply?," in 2011 35th WEDC International Conference. The Future of Water, Sanitation and Hygiene in Low-Income Countries: Innovation, Adaptation and Engagement in a Changing World, Loughborough, UK, 2011.

[5] P. Moriarty, S. Smits, J. Butterworth, and R. Franceys, "Trends in rural water supply: Towards a service delivery approach," Water Alternatives, vol. 6, pp. 329-349, 2013. 
[6] M. Munkonge and P. Harvey, "Assessing the potential for self-supply in Zambia," in 2009 34th WEDC International Conference-Water, Sanitation and Hygiene: Sustainable Development and Multisectoral Approaches, Addis Ababa, Ethiopia, 2009.

[7] S. Sutton, "Integrating a new approach: The example of self-supply," in 200934 th WEDC International Conference-Water, Sanitation and Hygiene: Sustainable Development and Multisectoral Approaches, Addis Ababa, Ethiopia, 2009.

[8] M. MacCarthy, J. Annis, and J. Mihelcic, "Unsubsidised self-supply in eastern Madagascar," Water Alternatives, vol. 6, pp. 424-438, 2013.

[9] D. B. Akers, M. F. Maccarthy, J. A. Cunningham, J. Annis, and J. R. Mihelcic, "Lead (Pb) contamination of self-supply groundwater systems in coastal madagascar and predictions of blood lead levels in exposed children," Environmental Science and Technology, vol. 49, pp. 2685-2693, 2015.

[10] Y. Chakava, R. Franceys, and A. Parker, "Private boreholes for Nairobi's urban poor: The stop-gap or the solution?," Habitat International, vol. 43, pp. 108-116, 2014.

[11] K. Nyarko, E. Awuah, and D. Ofori, "Self-supply schemes for community water supply in Ghana," in 200833 rd WEDC International Conference-Access to Sanitation and Safe Water: Global Partnerships and Local Actions, Accra, Ghana, 2008, pp. 421-425.

[12] L. Okotto, J. Okotto-Okotto, H. Price, S. Pedley, and J. Wright, "Socio-economic aspects of domestic groundwater consumption, vending and use in Kisumu, Kenya," Applied Geography, vol. 58, pp. 189-197, 2015.

[13] WHO, "Guidelines for drinking-water quality (2011)," in WHO web site. Accessed vol. 20, ed. Geneva (Switzerland): WHO (World Health Organization), 2012.

[14] G. Oluwasanya, J. Smith, and R. Carter, "Self-supply systems: Urban dug wells in Abeokuta, Nigeria," Water Science and Technology: Water Supply, vol. 11, pp. 172-178, 2011.

[15] Departamento Nacional de Planeación (DNP), Documento Conpes 3810: Política para el suministro de agua potable y saneamiento básico en la zona rural. Bogotá: DNP, 2014.

[16] R. Yin, Case study Research: Design and methods, 5th ed. Philadelphia: Sage, 2014.

[17] M. Bunch, K. Morrison, M. Parkes, and H. Venema, "Promoting health and well-being by managing for Social-Ecological resilience: The potential of integrating ecohealth and water resources management approaches," Ecology and Society, vol. 16, pp. 18, http://www. ecologyandsociety.org/vol16/iss1/art6/, 2011.

[18] Corporación Autónoma Regional del Valle del Cauca (CVC), "Cuencas del Valle del Cauca.” 2013 [Online]. Available: http://www.cvc.gov.co/vsm38cvc/data/RecursoHidrico/ aplicativos/Cuenca

[19] Corporación Autónoma Regional del Valle del Cauca (CVC), Aplicativo GeoCVC. Cali: CVC, 2012. 
[20] M. Roa-García, S. Brown, H. Schreier, and L. Lavkulich, "The role of land use and soils in regulating water flow in small headwater catchments of the Andes," Water Resources Research, vol. 47, pp. 12, W05510, doi:10.1029/2010WR009582, 2011.

[21] D. V. Chapman, Unesco, World Health Organization, and United Nations Environment Programme, Water Quality Assessments: A Guide to the Use of Biota, Sediments, and Water in Environmental Monitoring, 2nd ed. London: E\&FN Spon, 1996.

[22] C. Robson, Real World Research: A Resource for Users of Social Research Methods in Applied Settings, 3rd ed. Sussex, UK: John Wiley \& Sons, 2011.

[23] Comité Departamental de Cafeteros del Valle del Cauca (CDC), "Sistema de Información de la Caficultura para el Valle del Cauca," unpublished, 2003.

[24] I. Domínguez, "Participatory modelling for holistic understanding of catchment health and human health in andean rural microcatchments, the case of Calabazas," PhD dissertation, School of Agriculture, Food and Rural Development, Newcastle University, UK, 2014.

[25] Oxfam-DelAgua, "Oxfam-DelAgua water testing kit: Users manual," 2012 [Online]. Available: http://www.delagua.org/assets/docs/usermanuals/DeLagua_Brochure_v1_usermanual.pdf

[26] World Health Organization (WHO), Rapid assessment of drinking-water quality: A bandbook for implementation. Geneva: WHO, 2012.

[27] P. K. Jensen, G. Jayasinghe, W. van Der Hoek, S. Cairncross, and A. Dalsgaard, "Is there an association between bacteriological drinking water quality and childhood diarrhoea in developing countries?," Tropical Medicine and International Health, vol. 9, pp. 1210-1215, 2004.

[28] A. Parker, R. Youlten, M. Dillon, T. Nussbaumer, R. Carter, S. Tyrrel, et al., "An assessment of microbiological water quality of six water source categories in north-east Uganda," Journal of Water and Health, vol. 8, pp. 550-560, 2010.

[29] R. Johnston, "Beyond improved: Monitoring drinking water in the post-MDG era," in $36^{\text {th }}$ WEDC International Conference, Nakuru, Kenya, 2013 [Online]. Available: http:// wedc.lboro.ac.uk/resources/conference/36/Johnston-1801.pdf

[30] K. Levy, A. Hubbard, K. Nelson, and J. Eisenberg, "Drivers of water quality variability in northern coastal Ecuador," Environmental Science and Technology, vol. 43, pp. 1788-1797, 2009.

[31] A. Strauch and A. Almedom, "Traditional water resource management and water quality in rural Tanzania," Human Ecology, vol. 39, pp. 93-106, 2011.

[32] S. A. Esrey, "Water, waste, and well-being: A multicountry study," American Journal of Epidemiology, vol. 143, pp. 608-623, 1996. 
[33] J. Gentry-Shields and J. Bartram, "Human health and the water environment: Using the DPSEEA framework to identify the driving forces of disease," Science of the Total Environment, vol. 468-469, pp. 306-314, 2013.

[34] Instituto Nacional de Salud (INS), Estado de la vigilancia de la calidad del agua para consumo bumano, 2013. Bogotá: INS, 2014.

[35] S. Postel and B. Thompson, "Watershed protection: Capturing the benefits of nature's water supply services," Natural Resources Forum, vol. 29, pp. 98-108, 2005.

[36] T. Clasen, W. P. Schmidt, T. Rabie, I. Roberts, and S. Cairncross, "Interventions to improve water quality for preventing diarrhoea: Systematic review and meta-analysis," British Medical Journal, vol. 334, pp. 782-785, 2007.

[37] M. Leiter, J. Levy, S. Mutiti, M. Boardman, A. Wojnar, and H. Deka, "Drinking water quality in the Mount Kasigau region of Kenya: A source to point-of-use assessment," Environmental Earth Sciences, vol. 68, pp. 1-12, 2013.

[38] J. Wright, S. Gundry, and R. Conroy, "Household drinking water in developing countries: A systematic review of microbiological contamination between source and point-of-use," Tropical Medicine and International Health, vol. 9, pp. 106-117, 2004.

[39] G. Rosa and T. Clasen, "Estimating the scope of household water treatment in low- and medium-income countries," American Journal of Tropical Medicine and Hygiene, vol. 82, pp. 289-300, 2010.

[40] Departamento Administrativo Nacional de Estadística (DANE). Pagina de inicio, 2014 [Online]. Available: http://www.dane.gov.co/

[41] E. Lee and K. Schwab, "Deficiencies in drinking water distribution systems in developing countries," Journal of Water and Health, vol. 3, pp. 109-127, 2005.

[42] L. Fewtrell, R. B. Kaufmann, D. Kay, W. Enanoria, L. Haller, and J. M. Colford Jr., "Water, sanitation, and hygiene interventions to reduce diarrhoea in less developed countries: A systematic review and meta-analysis," Lancet Infectious Diseases, vol. 5, pp. 42-52, 2005.

[43] A. Kabirizi, R. Carter, J. Mpalanyi, and J. Ssebalu, "Self-help initiatives to improve water supplies in eastern and central Uganda," in 2005 31st WEDC International Conference: Maximizing the Benefits from Water and Environmental Sanitation, Kampala, Uganda, 2005, pp. 351-354.

[44] R. Keirle and C. Hayes, "A review of catchment management in the new context of drinking water safety plans," Water and Environment Journal, vol. 21, pp. 208-216, 2007.

[45] K. Onda, J. Lobuglio, and J. Bartram, "Global access to safe water: Accounting for water quality and the resulting impact on MDG progress," International Journal of Environmental Research and Public Health, vol. 9, pp. 880-894, 2012.

[46] S. Smits, B. van Koppen, P. Moriarty, and J. Butterworth, "Multiple-use services as an alternative to rural water supply services: A characterisation of the approach," Water Alternatives, vol. 3, pp. 102-121, 2010. 
[47] I. Domínguez, W. Torres-López, I. Restrepo-Tarquino, R. Oviedo-Ocaña, and I. Smout, "Livelihood factors, explaining water consumption in a (de facto) multiple uses water system in Colombia," Ingeniería y Universidad, vol. 18, no. 1, pp. 7-25, 2014.

[48] T. Gomiero, D. Pimentel, and M. G. Paoletti, "Is there a need for a more sustainable agriculture?," Critical Reviews in Plant Sciences, vol. 30, pp. 6-23, 2011. 
